RECORDS OF PHARMACEUTICAL
AND BIOMEDICAL SCIENCES

\title{
Gas Chromatography-Mass Spectrometry Analysis of Marine Seagrass Thalassodendron ciliatum Collected from Red Sea
}

\author{
Marwa S. Goda ${ }^{a}$, Enas E. Eltamany ${ }^{a}$ Eman S. Habib ${ }^{a}$, Hashem A. Hassanean ${ }^{a}$, Safwat A. Ahmed ${ }^{a}$, Reda \\ F. A. Abdelhameed ${ }^{a}$, and Amany K. Ibrahim ${ }^{a *}$ \\ ${ }^{a}$ Department of Pharmacognosy, Faculty of Pharmacy, Suez Canal University, 41522, Ismailia, Egypt
}

Received on: 16. 04.2020

Revised on: 25. 04. 2020

Accepted on: 01. 05. 2020

Correspondence Author:

Tel: +2001092638387

E-mail address:

am_kamal66@yahoo.com

\begin{abstract}
Marine organisms are considered as a treasure for discovery of bioactive metabolites. Seagrasses provide food and habitat for other marine organisms. They are widely distributed in tropical and subtropical regions. Seagrass Thalassodendron ciliatum (Forsk.) den Hartog is a very common seagrass species in the Red Sea. Several studies have proved its antioxidant, anti-inflammatory and antimicrobial potentials. Gas Chromatography-Mass spectrometry Analysis was performed for identification of existed phytochemicals. Herein, it is the first reported study explaining the lipoidal matter of $n$-hexane fraction of T. ciliatum using GC-MS technique. The obtained data revealed presence of saturated and unsaturated- long chain- fatty acids; tetradecanoic acid, eicosanoic acid, 9,12hexadecadienoic acid and 8,11,14-eicosatrienoic acid, in addition to other volatile compounds; 1-heneicosanol, 2,6-bis (1,1-dimethylethyl) phenol and 1-tridecanol. These compounds were previously assessed for their antibacterial, antifungal, antimicrobial and anti-inflammatory bioactivities. So, the previously reported antioxidant, anti-inflammatory and antimicrobial activities of Thalassodendron ciliatum may be attributed to these identified compounds.
\end{abstract}

Keywords: GC-MS, Thalassodendron ciliatum, tetradecanoic acid, 1heneicosanol, antimicrobial.

\section{Introduction}

The marine environment $(>70 \%$ of the planet's surface) possesses unique biological and chemical characters that play a vital role in discovery of many drug leads. Many marine-living organisms are soft bodied and/or sessile. Consequently, they have developed toxic secondary metabolites to defend themselves against predators (Eltamany, 2015). The Red Sea is considered as a precious natural source of bioactive compounds because of its distinctive features; lack of any river drainage, great marine organisms' biodiversity, and seasonal fluctuations of air and water temperatures. According to El- Ezz et al., several terpeniods, alkaloids, sterols and steroidal glycosides were 
reported in Red Sea marine organisms besides, other metabolites of diverse chemical classes (El-Ezz et al., 2017). Scientists classified marine organisms into different categories; Bacteria (ex. marine bacteria), Protocists (ex. algae), Plants (ex. sea grass) and Animals (ex. sponges, corals and tunicates). This biodiversity ensures presence of different classes of secondary metabolites that manifested beneficial biological activities. Sea grasses can be found all over the world except in the polar region. In many places, sea grasses cover extensive areas, which are usually called as sea grass beds. Thalassodendron ciliatum (Forsk.) den Hartog is commonly known as 'Majani kumbi', it is a very common seagrass species in the Red Sea. T. ciliatum is a tropical sea grass which can be classified as sub-tidal and not deepwater bed forming sea grass. Traditional healers prescribed seagrasses as an effective treatment for different ailments (Ibrahim et al., 2013; Mohammed et al., 2019). Some previous studies reported isolation and identification of different phytochemicals like caffeic acid, catechin, asebotin, quercetin-3-O- $\beta$-D-xylopyranoside, rutin, 6-Orhamnosyl-(1"' $\rightarrow$ 6"') glucopyranosyl asebogenin, diglyceride ester, $7 \beta$-hydroxy cholesterol, $7 \beta$ hydroxysitosterol, stigmasterol glucoside, $\beta$ sitosterol glucoside and ceramides, as shown in figure 1 (Hamdy et al., 2012; Ibrahim et al., 2013; Mohammed et al., 2014; Abdelhameed et al., 2018). Moreover, T. ciliatum (Forsk.) den Hartog showed a significant antioxidant, anti-inflammatory, antiviral and cytotoxic activities. So, further studies are needed for discovery of other natural compounds present in T. ciliatum. To the best of our knowledge, few previous studies were reported concerning chemical investigation of T. ciliatum. Herein, it is the first reported one explaining the lipoidal matter of $T$. ciliatum using GC-MS technique.

\section{Experimental Section}

\subsection{Marine material and chemicals}

Seagrass Thalassodendron ciliatum was collected from Sharm El-Sheikh, Egypt. It was taxonomically identified by Prof. Tarek Temraz Marine Science Department, Faculty of Science, Suez Canal University, Ismailia, Egypt. A voucher specimen was deposited in the herbarium section of Pharmacognosy Department, Faculty of Pharmacy, Suez Canal University, Ismailia, Egypt under the registration number SAA-41. Solvents used for extraction and fractionation were analytical grade, but subjected to distillation before use. While, solvents of HPLC grade were used for GC-MS analysis.

\subsection{Instruments}

Rotatory evaporator $\left(\mathrm{Buchi}^{\circledR}, \quad \mathrm{G}\right.$. Switzerland) was used for evaporation, while GC-MS instrument (TRACE GC Ultra Gas Chromatographs; THERMO Scientific Corporation, Waltham, Massachusetts, USA), coupled with a THERMO mass spectrometer detector (ISQ Single Quadrupole Mass Spectrometer, Thermo Scientific, San Jose, California, USA) was used for GC-MS analysis. 
Rec. Pharm. Biomed. Sci. B: 4 (2), 1-15, 2020<smiles>O=C(O)/C=C/c1ccc(O)c(O)c1</smiles>

Caffeic acid<smiles>Oc1cc(O)c2c(c1)OC(c1ccc(O)c(O)c1)C(O)C2</smiles>

Catechin

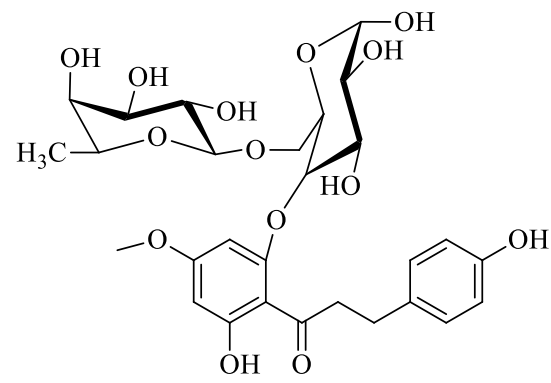

6-O-rhamnosyl-(1"'-6"') glucopyranosyl asebogenin

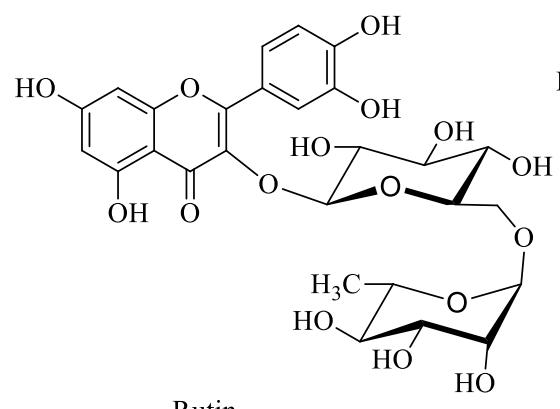<smiles>O=c1c(OC2OCC(O)C(O)C(O)C2O)c(-c2ccc(O)c(O)c2)oc2cc(O)cc(O)c12</smiles><smiles>COc1cc(O)c(C(=O)CCc2ccc(O)cc2)c(OC2C(O)CC(O)C(O)C(O)C2O)c1</smiles>

Quercetin-3-O- $\beta$-D-xylopyranoside

Asebotin<smiles>CCC(CC[C@H](C)[C@H]1CC[C@H]2[C@@H]3[C@H](O)C=C4CC(O)CC[C@]4(C)[C@H]3CC[C@@]21C)C(C)C</smiles>

$7 \beta$-hydroxysitosterol<smiles>CCC(/C=C/[C@H](C)C1CCC2[C@H]3CC=C4CC(OC5C(O)COC(O)C(O)C(O)C5O)CCC4(C)[C@H]3CC[C@@]12C)C(C)C</smiles>

$7 \beta$-hydroxy cholesterol<smiles>CCCC(C)C</smiles>

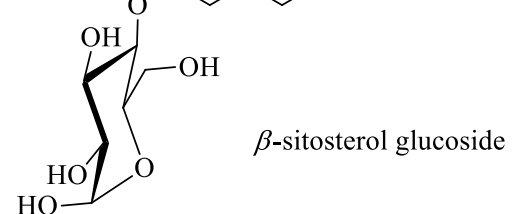<smiles>CCCCCC(C)CCCCC(O)C(=O)N[C@@H](CO)[C@@H](O)[C@H](O)CCCCCC(C)(C)CCCC</smiles>

Figure 1: structures of previously isolated compounds from Thalassodendron ciliatum 
Table 1: Fatty acid methyl esters of Thalassodendron ciliatum

\begin{tabular}{|c|c|c|c|c|c|c|}
\hline & $\begin{array}{l}\text { Retention } \\
\text { time (min) }\end{array}$ & Name of compound & Structure & Area \% & $\begin{array}{l}\text { Molecular } \\
\text { formula }\end{array}$ & $\begin{array}{l}\text { Molecular } \\
\text { weight }\end{array}$ \\
\hline 1 & 4.98 & $\begin{array}{l}\text { Dodecanoic acid, methyl } \\
\text { ester }\end{array}$ & & 0.55 & $\mathrm{C}_{13} \mathrm{H}_{26} \mathrm{O}_{2}$ & 214 \\
\hline 2 & 9.97 & $\begin{array}{c}\text { Methyl-13- } \\
\text { methyltetradecanoate }\end{array}$ & & 1.48 & $\mathrm{C}_{16} \mathrm{H}_{32} \mathrm{O}_{2}$ & 256 \\
\hline 3 & 12.18 & $\begin{array}{l}\text { Pentadecanoic acid, } \\
\text { 14-methyl-, methyl ester }\end{array}$ & & 0.72 & $\mathrm{C}_{17} \mathrm{H}_{34} \mathrm{O}_{2}$ & 270 \\
\hline 4 & 10.79 & $\begin{array}{l}\text { Tetradecanoic acid, } \\
\text { 12-methyl-, methyl ester }\end{array}$ & & 6.07 & $\mathrm{C}_{16} \mathrm{H}_{32} \mathrm{O}_{2}$ & 256 \\
\hline 5 & 12.57 & $\begin{array}{l}\text { 9-Hexadecenoic acid, } \\
\text { methyl ester }\end{array}$ & & 4.68 & $\mathrm{C}_{17} \mathrm{H}_{32} \mathrm{O}_{2}$ & 268 \\
\hline 6 & 13.08 & $\begin{array}{l}\text { Pentanoic acid, } \\
\text { 2-acetyl-4-methyl-, } \\
\text { methyl ester }\end{array}$ & & 21.13 & $\mathrm{C}_{9} \mathrm{H}_{16} \mathrm{O}_{3}$ & 172 \\
\hline 7 & 15.27 & $\begin{array}{l}\text { Tetradecanoic acid, } \\
\text { methyl ester }\end{array}$ & & 11.77 & $\mathrm{C}_{15} \mathrm{H}_{30} \mathrm{O}_{2}$ & 242 \\
\hline 8 & 15.74 & $\begin{array}{l}\text { 2-hydroxy- Hexadecanoic } \\
\text { acid, methyl ester }\end{array}$ & & 0.2 & $\mathrm{C}_{17} \mathrm{H}_{34} \mathrm{O} 3$ & 286 \\
\hline 9 & 16.57 & $\begin{array}{l}\text { 9,12-Hexadecadienoic } \\
\text { acid, methyl ester }\end{array}$ & & 1.14 & $\mathrm{C}_{17} \mathrm{H}_{30} \mathrm{O}_{2}$ & 266 \\
\hline 10 & 16.88 & $\begin{array}{l}\text { 11-Octadecenoic acid, } \\
\text { methyl ester }\end{array}$ & & 2.13 & $\mathrm{C}_{19} \mathrm{H}_{36} \mathrm{O}_{2}$ & 296 \\
\hline 11 & 17.01 & $\begin{array}{l}\text { 10-Octadecenoic acid, } \\
\text { methyl ester }\end{array}$ & & 5.40 & $\mathrm{C}_{19} \mathrm{H}_{36} \mathrm{O}_{2}$ & 296 \\
\hline 12 & 17.47 & $\begin{array}{c}\text { Eicosanoic acid, methyl } \\
\text { ester }\end{array}$ & & 11.25 & $\mathrm{C}_{21} \mathrm{H}_{42} \mathrm{O}_{2}$ & 326 \\
\hline 13 & 18.78 & $\begin{array}{l}\text { Octadecanoic acid, } \\
\text { 17-methyl-, methyl ester }\end{array}$ & & 2.21 & $\mathrm{C}_{20} \mathrm{H}_{40} \mathrm{O}_{2}$ & 312 \\
\hline 14 & 19.31 & $\begin{array}{l}\text { 8,11,14-Eicosatrienoic } \\
\text { acid, methyl ester }\end{array}$ & & 0.4 & $\mathrm{C}_{21} \mathrm{H}_{36} \mathrm{O}_{2}$ & 320 \\
\hline 15 & 19.56 & $\begin{array}{l}\text { Nonadecanoic acid, } \\
\text { methyl ester }\end{array}$ & & 1.41 & $\mathrm{C}_{20} \mathrm{H}_{40} \mathrm{O}_{2}$ & 312 \\
\hline
\end{tabular}


Rec. Pharm. Biomed. Sci. B: 4 (2), 1-15, 2020

$16 \quad 21.24$

11-Eicosenoic acid, methyl ester

$0.55 \quad \mathrm{C}_{21} \mathrm{H}_{40} \mathrm{O}_{2}$

324

$17 \quad 23.65$

Heneicosanoic acid, methyl ester

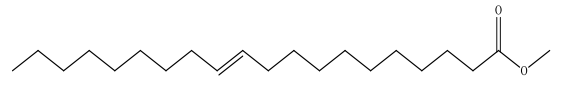

$1.14 \quad \mathrm{C}_{22} \mathrm{H}_{44} \mathrm{O}_{2}$

340

$18 \quad 20.27$

22-Tricosenoic acid, methyl ester

$0.56 \quad \mathrm{C}_{23} \mathrm{H}_{44} \mathrm{O}_{2}$

352

$19 \quad 29.06$

15-Tetracosenoic acid, methyl ester

$0.59 \quad \mathrm{C}_{25} \mathrm{H}_{48} \mathrm{O}_{2}$

380

Methyl

$20 \quad 30.40$

23-methyl-tetracosa-5,9dienoate

$\mathrm{C}_{26} \mathrm{H}_{48} \mathrm{O}_{2}$

392

$21 \quad 32.20$

Methyl

5,9-docosadienoate

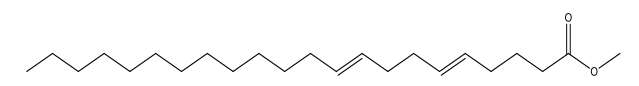

4.92

$\mathrm{C}_{23} \mathrm{H}_{42} \mathrm{O}_{2}$

350

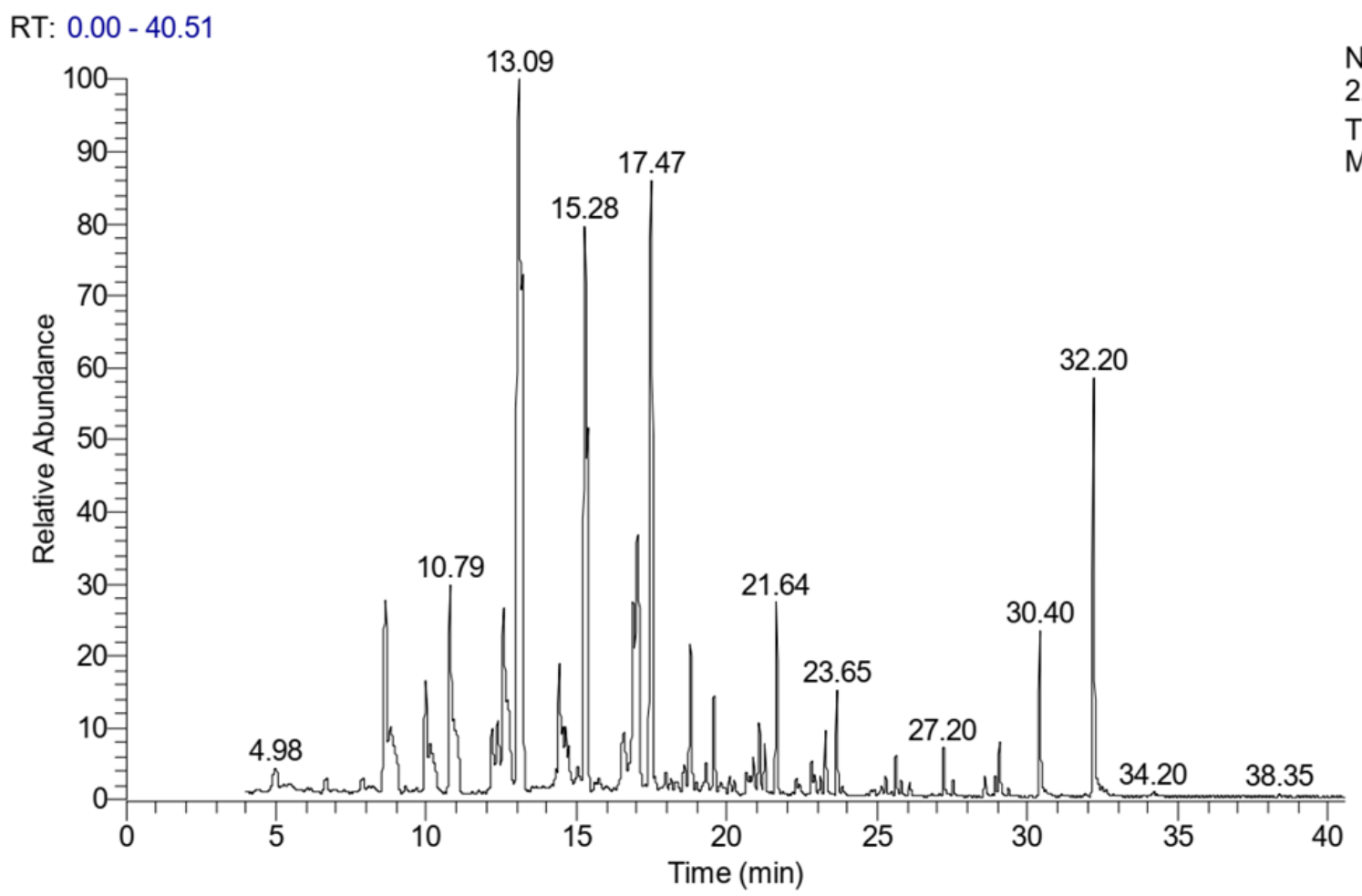

Figure 2: Chromatogram of GC-MS analysis of fatty acid methyl esters of sea grass Thalassodendron ciliatum 


\subsection{Extraction and fractionation of marine material}

Thalassodendron ciliatum of $90 \mathrm{~g}$. weight was dried, grounded and soaked in methanol for 3 days at room temperature. This soaking or extraction process was repeated for 3 times to ensure complete extraction of active metabolites. Then, the combined methanol extract was concentrated under vacuum resulting in $47.4 \mathrm{~g}$. residue. The residue was fractionated using open column technique with $n$-hexane, ethyl acetate and methanol gradient elution. Fractions of different polarities were also evaporated under vacuum and weighed. The resulting $n$-hexane fraction of $5.76 \mathrm{~g}$. was subjected for Gas Chromatography-Mass spectrometry [GC-MS] analysis.

\subsection{GC-MS analysis of $\boldsymbol{n}$-hexane extract}

\subsubsection{Preparation of unsaponifiable matter}

One gram of $n$ - hexane fraction was refluxed with 50 $\mathrm{ml}$ of $10 \%$ ethanolic potassium hydroxide and $20 \mathrm{ml}$ benzene at $90{ }^{\circ} \mathrm{C}$ for 24 hours for saponification process. After this, the mixture was evaporated and concentrated to its third volume under vacuum. 100 $\mathrm{ml}$ of distilled water were added to the residue and then the aqueous solution was partitioning with diethyl ether $(5 \times 100 \mathrm{ml})$ for several times using a separating funnel till complete extraction of unsaponifiable matter. The collected extracts of diethyl ether were washed with distilled water for several times, then dried over anhydrous sodium sulphate. The residue weighed 0.46 g. of unsaponified matter (Eltamany, 2010).

\subsubsection{Preparation of fatty acid methyl ester}

The aqueous alkaline solution left after separation of unsaponified matter was acidified with conc. $\mathrm{HCl}$ using litmus paper as indicator for $\mathrm{pH}$. The liberated fatty acids were extracted with ether for several times using a separating funnel till complete extraction. The collected extracts of ether were washed with distilled water for several times till washing is neutral to litmus paper, then dried over anhydrous sodium sulphate. The residue weighed $0.34 \mathrm{~g}$. of free fatty acids. For preparation of fatty acid methyl ester, $0.2 \mathrm{~g}$. of residue was refluxed with $50 \mathrm{ml}$ absolute methanol and $2.5 \mathrm{ml}$ conc. $\mathrm{H}_{2} \mathrm{SO}_{4}$ at $85{ }^{\circ} \mathrm{C}$ for 2 hours. After cooling, the mixture was diluted with $100 \mathrm{ml}$ of distilled water and extracted with diethyl ether for several times using a separating funnel till complete extraction of fatty acid methyl esters. The collected extracts of diethyl ether were washed with distilled water for several times till neutral to litmus paper, then dried over anhydrous sodium sulphate (Eltamany, 2010).

\subsection{3. $\quad G C$-MS analysis}

Both fatty acid methyl esters and unsaponifiable matter were analyzed using GC-MS technique. The GC-MS system was equipped with a TG-WAX MS column $(30 \mathrm{~m} \times 0.251 \mathrm{~mm}$ daily, $0.1 \mathrm{~mm}$ film thickness). Analysis was carried out using helium as a carrier gas at a constant flow rate of $1.0 \mathrm{ml} / \mathrm{min}$. Diluted samples (1:10 chloroform, $v / v)$ of $0.2 \mu \mathrm{l}$ of the mixtures were always injected automatically in the splitless mode. The injector and MS transfer line temperature were set at $280^{\circ} \mathrm{C}$. The separation technique for fatty acid methyl esters was carried out using the following temperature program: $150^{\circ} \mathrm{C}$ for $4 \mathrm{~min}$ as an initial temperature 
Rec. Pharm. Biomed. Sci. B: 4 (2), 1-15, 2020

Table 2: Hydrocarbons and their derivatives of Thalassodendron ciliatum

\begin{tabular}{|c|c|c|c|c|c|c|}
\hline & $\begin{array}{l}\text { Retention } \\
\text { time (min) }\end{array}$ & Name of compound & Structure & Area \% & $\begin{array}{l}\text { Molecular } \\
\text { formula }\end{array}$ & $\begin{array}{l}\text { Molecular } \\
\text { weight }\end{array}$ \\
\hline 1 & 22.37 & $\begin{array}{l}\text { 2,3-dicyano-7,7-dimethyl } \\
\text {-5,6-benzonorbornadiene }\end{array}$ & & 2.36 & $\mathrm{C}_{15} \mathrm{H}_{12} \mathrm{~N}_{2}$ & 220 \\
\hline 2 & 22.52 & $\begin{array}{l}\text { Phenol, } \\
\text { 2,6-bis (1,1-dimethylethyl) }\end{array}$ & & 6.32 & $\mathrm{C}_{14} \mathrm{H}_{22} \mathrm{O}$ & 206 \\
\hline 3 & 24.05 & 1-Hexadecanol & & 1.0 & $\mathrm{C}_{16} \mathrm{H}_{34} \mathrm{O}$ & 242 \\
\hline 4 & 26.03 & Cyclotetradecane & & 2.71 & $\mathrm{C}_{14} \mathrm{H}_{28}$ & 196 \\
\hline 5 & 27.39 & 1-Tridecanol & & 2.03 & $\mathrm{C}_{13} \mathrm{H}_{28} \mathrm{O}$ & 200 \\
\hline 6 & 28.19 & 1-Pentadecanol & & 6.60 & $\mathrm{C}_{15} \mathrm{H}_{32} \mathrm{O}$ & 228 \\
\hline 7 & 28.39 & Penta-3,4-dienoic acid & & 9.49 & $\mathrm{C}_{5} \mathrm{H}_{6} \mathrm{O}_{2}$ & 98 \\
\hline 8 & 28.59 & 2-Hexadecanone & & 1.58 & $\mathrm{C}_{16} \mathrm{H}_{32} \mathrm{O}$ & 240 \\
\hline 9 & 29.46 & $\begin{array}{l}\text { 2-Pentadecanone, } \\
\text { 6,10,14-trimethyl }\end{array}$ & & 1.03 & $\mathrm{C}_{18} \mathrm{H}_{36} \mathrm{O}$ & 268 \\
\hline 10 & 29.63 & $\begin{array}{l}\text { Cyclopropane, } \\
\text { 1-methyl-1-(1- } \\
\text { methylethyl)-2-nonyl }\end{array}$ & & 1.10 & $\mathrm{C}_{16} \mathrm{H}_{32}$ & 224 \\
\hline 11 & 30.26 & 1-Heneicosanol & & 13.94 & $\mathrm{C}_{21} \mathrm{H}_{44} \mathrm{O}$ & 312 \\
\hline 12 & 30.49 & Eicosane & & 0.7 & $\mathrm{C}_{20} \mathrm{H}_{42}$ & 282 \\
\hline 13 & 30.61 & 2-Heptadecanone & & 3.58 & $\mathrm{C}_{17} \mathrm{H}_{34} \mathrm{O}$ & 254 \\
\hline 14 & 32.17 & Cyclopentane, decyl & & 1.16 & $\mathrm{C}_{15} \mathrm{H}_{30}$ & 210 \\
\hline 15 & 32.32 & $\begin{array}{l}\text { 1-Dodecanol, } \\
\text { 3,7,11-trimethyl }\end{array}$ & & 12.44 & $\mathrm{C}_{21} \mathrm{H}_{44} \mathrm{O}$ & 312 \\
\hline 16 & 32.53 & $\begin{array}{l}\text { Methyl n-hexadecyl } \\
\text { ketone }\end{array}$ & & 3.21 & $\mathrm{C}_{18} \mathrm{H}_{36} \mathrm{O}$ & 268 \\
\hline
\end{tabular}




18 Octane, 1,1'-oxybis

with an increasing rate of $5.0^{\circ} \mathrm{C} / \mathrm{min}$ till $280^{\circ} \mathrm{C}$ as a final temperature and held for $4 \mathrm{~min}$. While, the temperature program for unsaponifiable matter was programmed at an initial temperature $50{ }^{\circ} \mathrm{C}$ (hold 2 $\min$ ) to $150{ }^{\circ} \mathrm{C}$ with an increasing rate of $7{ }^{\circ} \mathrm{C} / \mathrm{min}$ then to $270{ }^{\circ} \mathrm{C}$ with an increasing rate $5^{\circ} \mathrm{C} / \mathrm{min}$ (hold $2 \mathrm{~min}$ ) then to $310{ }^{\circ} \mathrm{C}$ as a final temperature at an increasing rate of $3.5^{\circ} \mathrm{C} / \mathrm{min}$ (hold $10 \mathrm{~min}$ ). For GC/MS detection an electron ionization system with ionization energy of $70 \mathrm{eV}$ was used with a spectral range of $m / z \quad 40-450$. Identification of the phytochemical constituents was carried out by comparison of their retention time and fragmentation pattern of mass spectra with those of published data and/or with those of the Wiley 9 and NIST08 mass spectral libraries. The quantification of all the identified components was investigated using a percent relative peak area (Elkhateeb et al., 2019).

\section{Results and Discussion}

\subsection{GC-MS analysis of fatty acid methyl ester}

More than 40 fatty acid methyl esters were identified in the saponifiable part of the $n$-hexane fraction of T. ciliatum (Table 1 ). The saturated fatty acid methyl ester derivatives represented $73.5 \%$ of total fatty acids in the lipoidal matter of $T$. ciliatum while unsaturated fatty acid constituted $26.5 \%$ of total fatty acid content. According to the obtained GC chromatogram (Figure 2), the major fatty acid methyl ester derivatives recorded were; 2-acetyl-4methyl-pentanoic (21.13\%) tetradecanoic acid (11.77\%) and eicosanoic acid (11.25\%). Moreover, methyl esters of 12-methyl- tetradecanoic acid, 10octadecenoic acid, 5,9-docosadienoic acid, 17methyl-octadecanoic acid, 9-hexadecenoic acid (palmitoleic acid), 
Rec. Pharm. Biomed. Sci. B: 4 (2), 1-15, 2020
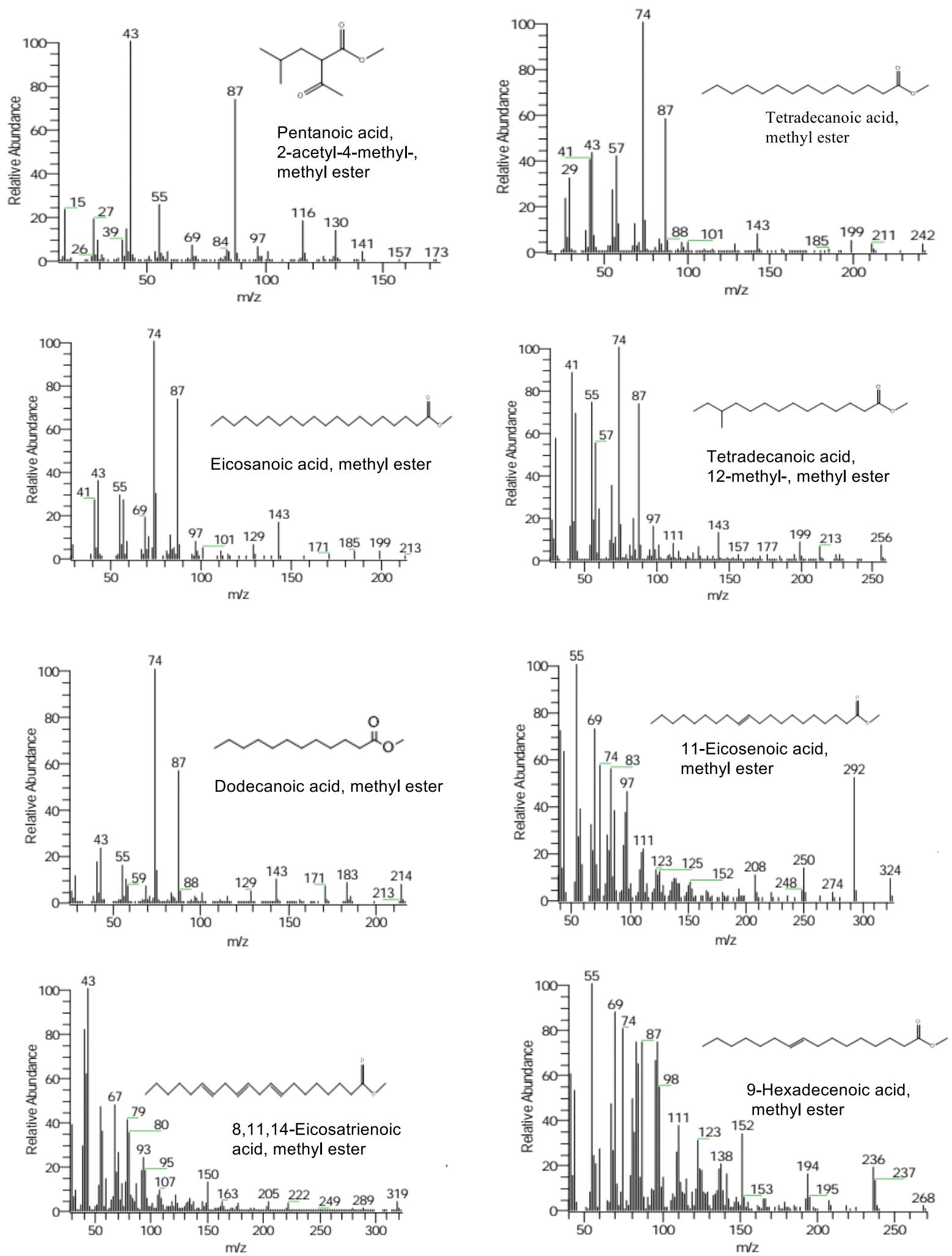

Figure 3: Mass spectra of some phytochemicals listed in table 1. 


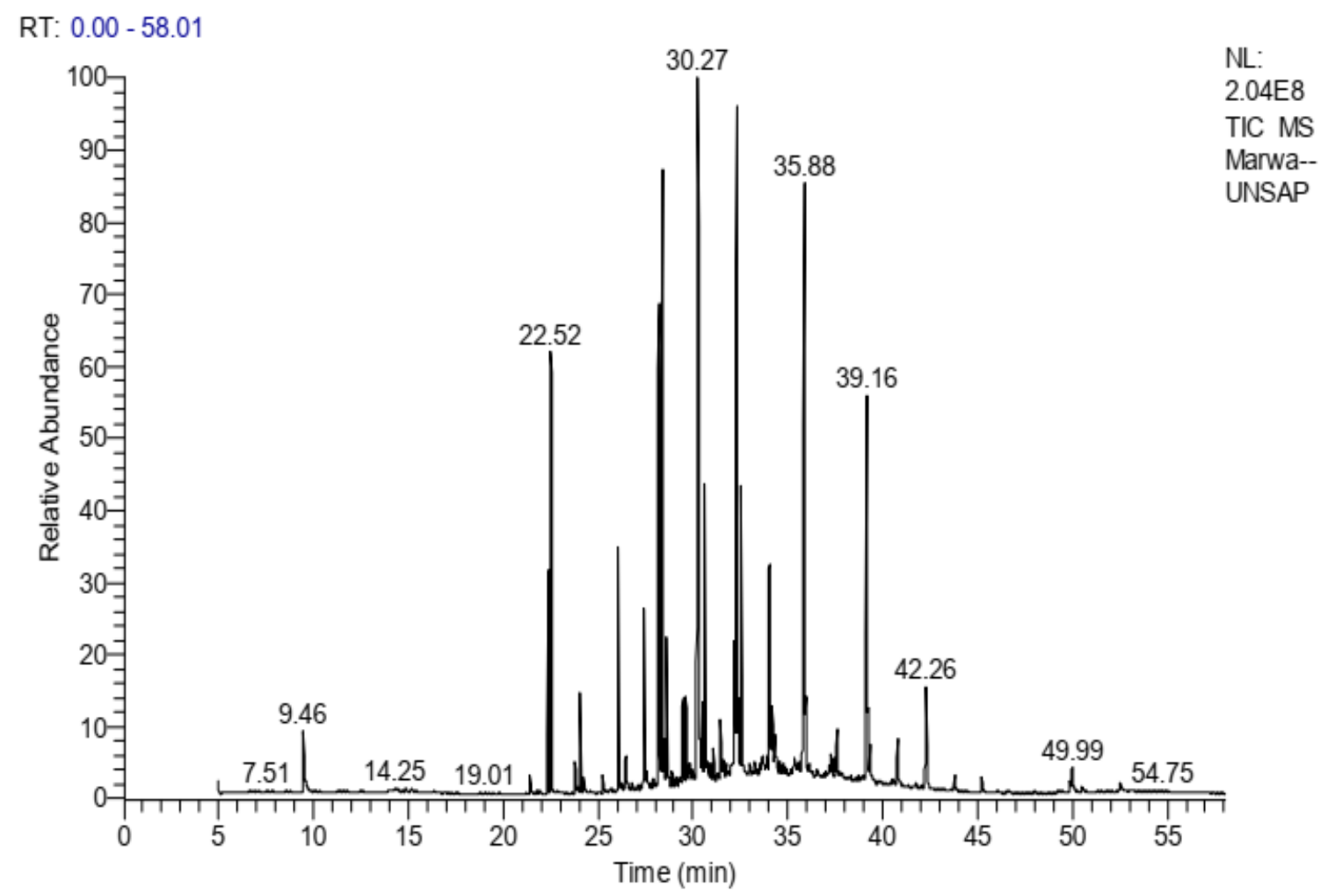

Figure 4: Chromatogram of GC-MS analysis of unsaponifiable matter of sea grass Thalassodendron ciliatum.

11-octadecenoic acid, 23-methyl-tetracosa-5,9dienoic acid, 13-methyl-tetradecanoic acid, nonadecanoic acid, 9,12-hexadecadienoic acid and heneicosanoic acid were also detected. In addition, methyl esters of dodecanoic acid (lauric acid), 14methyl-pentadecanoic acid, 2-hydroxy-hexadecanoic acid, 8,11,14-eicosatrienoic acid, 11eicosenoic acid, 22-tricosenoic acid and 15tetracosenoic acid (nervonic acid) were also present in traces. Figure 3 represents the mass spectra of selected phytochemicals that listed in Table1.

Tetradecanoic acid, with area percentage of 11.77 , possessed antifungal, antibacterial and hypercholesterolemic activities
(Elaiyaraja and Chandramohan, 2016). Moreover, it showed a larvicidal activity against Aedes aegypti and this was highly supported by other study of a larvicidal activity of 12-methyl- tetradecanoic acid derivative, with $\%$ area of 6.07 , against Polychaete Hydroides elegans (Xu et al., 2009; Sivakumar et al., 2011). Among series of tested saturated fatty acids, lauric acid and myristic acid were the most active bactericides against Gram negative bacteria but with lower activity than unsaturated fatty acids (Galbraith et al., 1971). In general, it is known that long-chain unsaturated fatty acids inhibit bacterial growth by disruption of bacterial fatty acid synthesis. Unsaturated fatty acids are more 

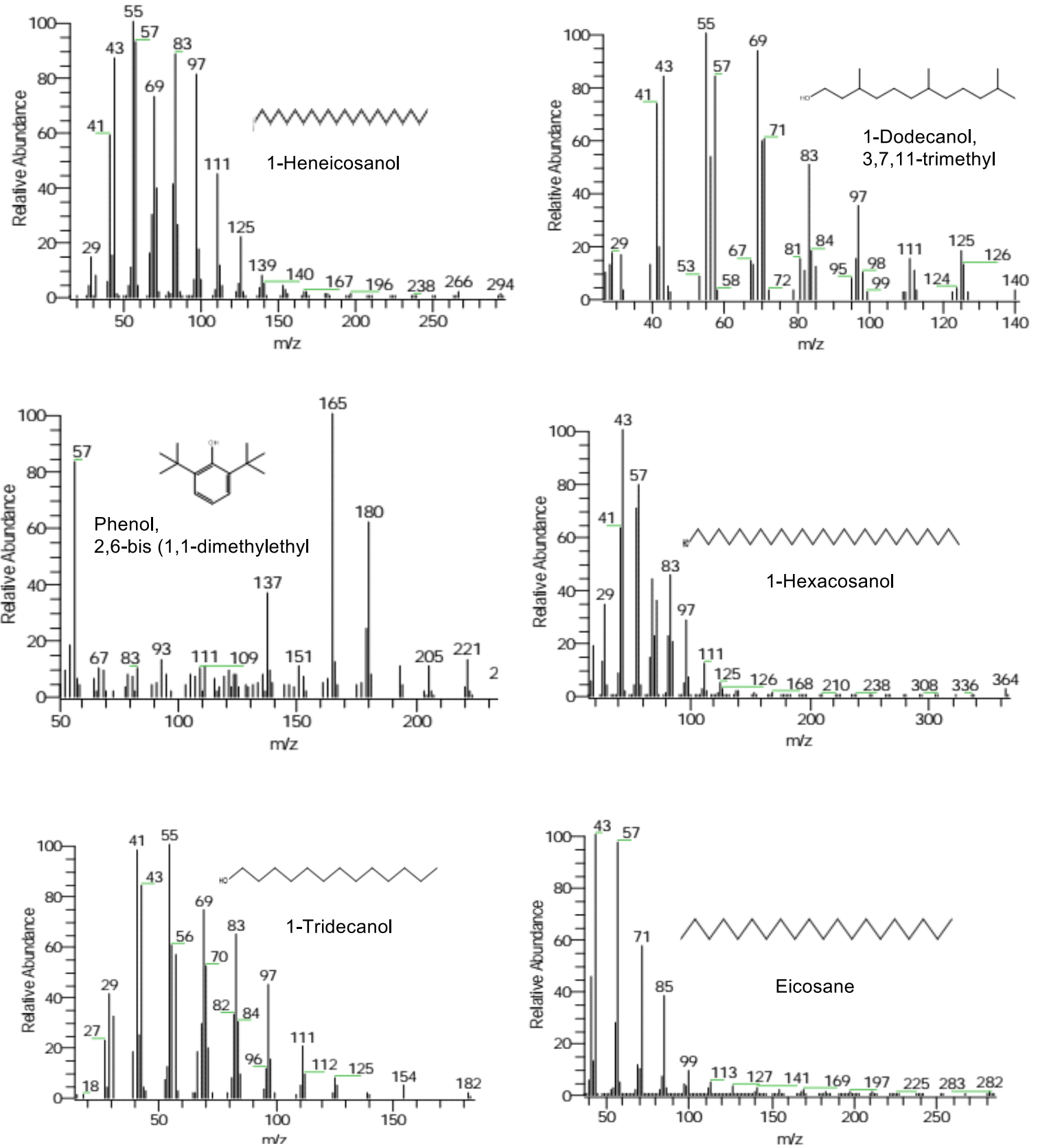

Figure 5: Mass spectra of some phytochemicals listed in table 2. 
active than the corresponding saturated fatty acids. The bacterial growth inhibition is enhanced with the increase of double bonds present in the molecules (Skalicka-Woz'niak et al., 2010). Based on this, our reported unsaturated long chain fatty acids, 5,9docosadienoic acid, 23-methyl-tetracosa-5,9-dienoic acid, 9,12-Hexadecadienoic acid and 8,11,14eicosatrienoic acid, may have antibacterial inhibition activity and further biological studies are needed. Moreover, unsaturated fatty acids are essential for normal growth of cells especially of blood vessels and nerves, integrity of cell structure, as well as the ability to lower cholesterol levels of the blood (Igwe and Okwu, 2013).

Both saturated fatty acids of chain lengths C-8 to C18 and unsaturated fatty acids of chain length C-11 to $\mathrm{C}-24$ were assessed for their antioxidant capacity. The saturated fatty acids, octanoic (C-8) to undecanoic acid (C-11) did not exhibit antioxidant activity. However, lauric acid, tridecanoic acid and myristic acid, displayed 60, 85, and $71 \%$ antioxidant activities, respectively. For unsaturated long chain fatty acids of C-20, cis-11-eicosenoic acid was the most active antioxidant fatty acid followed by 8,11,14-eicosatrienoic acid which manifested also a significant inhibition of COX-II enzyme activity, inflammation causing enzyme (Henry et al., 2002). Furthermore, palmitoleic acid (9-hexadecenoic acid) present in a considerable amount in $T$. cilliatum saponified part $(4.86 \%)$ as shown in table 1 , was reported previously to exert strong antiinflammatory effect (Astudillo et al., 2017)

GC-MS analysis of unsaponifiable matter

The GC chromatogram of the unsaponified fraction of $T$. ciliatum hexane extract (Figure4) demonstrated the presence of 59 compounds. The identified constituents consisted of $68 \%$ oxygenated compounds and $32 \%$ unoxygenated ones. Some of the determined compounds were listed in table 2 based on their predominance or previously reported biological activity. From table 2, we noticed that 1heneicosanol was the most predominant volatile phytochemical with $\%$ area of 13.94. 1Heneicosanol showed a significant antifungal and antibacterial activities against Candida albicans and C. krusei, Staphylococcus aureus and Pseudomonas aeruginosa (Arancibia et al., 2016). Likewise, 3,7,11-trimethy-11-dodecanol, known as hexahydrofarnesol, was also major phytochemical with $\%$ area of 12.44 followed by 1,1'-oxybisoctane with $\%$ area of 10.16 . Other peaks were determined like penta-3,4-dienoic acid, 1pentadecanol, 2,6- bis (1,1-dimethylethyl) phenol, 1-hexacosanol, 2-heptadecanone, 1-octadecanol, 1tridecanol, cyclotetradecane, 2,3-dicyano-7,7dimethyl-5,6-benzonorbornadiene, 1-hexadecanol, 2-hexadecanone, 6,10,14-trimethyl-2pentadecanone, eicosane and 1-methyl-1-(1methylethyl)-2-nonyl-cyclopropane. Few steroidal compounds were identified as cholestane-3-ol and stigmast-5-en-3-ol. According to previous studies, 2,6-bis (1,1-dimethylethyl) phenol exhibited antiinflammatory, antifungal, antimicrobial, antioxidant, antimalarial activities (Costantino et al., 1993; Elaiyaraja and Chandramohan, 2016). 1Hexacosanol was found to have larvicidal activity against Chromolaena odorata through acetylcholinesterase inhibition mechanism (Gade et al., 2017). 1-Dodecanol and 1-tridecanol could be 
useful for the natural mosquito control agents against Aedes aegypti (Tabanca et al., 2014). Belakhdar and coworkers proved the antibacterial, antimicrobial and cytotoxic activity of eicosane (Belakhdar et al., 2015).

Mass spectra of some selected phytochemicals were shown in figure 5.

\section{Conclusion}

To the best of our knowledge this is the first reported investigation of $T$. ciliatum lipoidal content. Our results of GC/MS analysis revealed the presence of saturated fatty acids, tetradecanoic acid (myristic acid) and dodecanoic acid (lauric acid), in addition to unsaturated fatty acids, 8,11,14-eicosatrienoic acid, 11-eicosenoic acid and 9-hexadecenoic acid (palmitoleic acid) in the saponifiable part of $T$. ciliatum hexane fraction. Moreover, the following volatile phytochemical compounds were detected; 1heneicosanol, 2,6-bis (1,1-dimethylethyl) phenol, eicosane, 1-hexacosanol and 1-tridecanol.

These phytochemicals may be the responsible for the reported antimicrobial, antioxidant and antiinflammatory activities of sea grass $T$. ciliatum

\section{Acknowledgement}

We would like to thank Prof. Tarek Temraz, Marine Science Department, Faculty of Science, Suez Canal University, Ismailia, Egypt for his identification of marine seagrass Thalassodendron ciliatum collected from Egyptian Red Sea.

\section{Conflict of interest}

There is no conflict of interest

\section{References}

Abdelhameed, R. F., Ibrahim, A. K., Yamada, K., Ahmed, S. A., 2018. Cytotoxic and antiinflammatory compounds from Red Sea grass Thalassodendron ciliatum. Medicinal Chemistry Research, 27, 1238-1244.

Arancibia, L. A., Naspi, C. V., Cecilia, V., Pucci, G. N., Arce, M., E., Colloca, C. B., 2016. Biological activity of 1-heneicosanol isolated from Senecio coluhuapiensis, an endemic species from Patagonia, Argentina. The Pharmaceutical and Chemical Journal, 3(4), 73-77.

Astudillo, A. M., Meana, C., Guijas, C, Pereira, L., Lebrero, P., Balboa,M. A., Balsinde, J., 2017. Occurrence and Biological Activity of Palmitoleic Acid Isomers in Phagocytic Cells. The Journal of Lipid Research, 59(2), 237-249.

Belakhdar, G., Benjouad, A., Abdennebi, E. H., 2015. Determination of some bioactive chemical constituents from Thesium humile Vahl. Journal of Materials and Environmental Science, 6(10), 27782783.

Costantino, L., Parenti, C., Di Bella, M., Zanoli, P., Baraldi, M., 1993. Anti-Inflammatory Activity of Newly Synthesized 2,6-bis-(1,1-Dimethylethyl) Phenol Derivatives. Pharmacological Research, 27(4), 349-358.

Elaiyaraja, A., Chandramohan, G., 2016. Comparative phytochemical profile of Indoneesiella echioides (L.) Nees leaves using GC-MS. Journal of Pharmacognosy and Phytochemistry, 5(6), 158-171. El-Ezz, R. A., Ibrahim, A., Habib, E., Wahba, A., Kamel, H., Afifi, A., Hassanean, H., Ahmed, S, 2017. Review of natural products from marine 
organisms in the Red sea. Vol. International Journal of Pharmaceutical Sciences and Research, 8(3), 940974.

Elkhateeb W. A., Daba, G. M., Sheir, D., El-Dein, A. N., Fayad, W., Elmahdy, E. M., Shaheen, M. N. F., Thomas, P. W., Wen, D., 2019. GC-MS analysis and in-vitro hypocholesterolemic, anti-rotavirus, antihuman colon carcinoma activities of the crude extract of a Japanese Ganoderma spp. Egyptian Pharmaceutical Journal, 18, 102-110.

Eltamany, E. E, 2010. Chemistry and biology of Achillea fragrantissima present in Sinai, a thesis for MSc degree, Faculty of pharmacy, Suez Canal University.

Eltamany, E.E., 2015. Bioactive metabolites from some marine organisms, a thesis for $\mathrm{PhD}$ degree, Faculty of pharmacy, Suez Canal University.

Gade, S., Rajamanikyam, M., Vadlapudi, V., Nukala, K. M., Aluvala, R., Giddigari, C., Karanam, N. J., Barua, N. C., Pandey, R., Upadhyayula, V. S. V., Sripadi, P., Amanchy, R., Upadhyayul, S. M., 2017. Acetylcholinesterase inhibitory activity of stigmasterol \& hexacosanol is responsible for larvicidal and repellent properties of Chromolaena odorata. Biochimica et Biophysica Acta (BBA) General Subjects, 1861(3), 541-550.

Galbraith, H., Miller, T. B., Paton, A. M., Thompson, J. K., 1971. Antibacterial Activity of Long Chain Fatty Acids and the Reversal with Calcium, Magnesium, Ergocalciferol and Cholesterol. Journal of Applied Bacteriology, 34(4), 803-813.

Hamdy, A. A., Mettwally, W. S. A., El Fotouh, M. A., Rodriguez, B., El-Dewany, A. I., El-Toumy, S.
A. A., Hussein, A. A., 2012. Bioactive Phenolic Compounds from the Egyptian Red Sea Seagrass Thalassodendron ciliatum. Z. Naturforsch, 67c, 291 $-296$.

Henry, G. E., Momin, R. A., Nair, M. G., Dewitt, D. L., 2002. Antioxidant and Cyclooxygenase Activities of Fatty Acids Found in Food. Journal of Agricultural and Food Chemistry, 50(8), 2231-2234. Ibrahim, A. K., Youssef, A. I., Arafa, A., Foad, R., Radwan, M. M., Ross, S., Hassanean, H. A., Ahmed, S. A., 2013. Anti- $\mathrm{H}_{5} \mathrm{~N}_{1}$ virus new diglyceride ester from the Red Sea grass Thallasodendron ciliatum. Natural Product Research, 27(18), 1625-1632.

Igwe, O. U., Okwu, D. E., 2013. GC-MS evaluation of bioactive compounds and antibacterial activity of the oil fraction from the seeds of Brachystegia eurycoma (HARMS). Asian Journal of Plant Science and Research, 3(2), 47-54.

Mohammed, M. M. D., Hamdy, A. A., El-Fiky, N. M., Mettwally, W. S. A., El-Beih, A. A., Kobayashi, N., 2014. Anti-influenza A virus activity of a new dihydrochalcone diglycoside isolated from the Egyptian seagrass Thalassodendron ciliatum (Forsk.). Natural Product Research, 28(6), 377-382. Sivakumar, R., Jebanesan, A., Govindarajan, M., Rajasekar, P., 2011. Larvicidal and repellent activity of tetradecanoic acid against Aedes aegypti (Linn.) and Culex quinquefasciatus (Say.) (Diptera: Culicidae). Asian Pacific Journal of Tropical Medicine, 4, 706-710.

Skalicka-Woz'niak, K., Los, R., Głowniak, K., Malm, A., 2010. Antimicrobial Activity of Fatty 
Rec. Pharm. Biomed. Sci. B: 4 (2), 1-15, 2020

Acids from Fruits of Peucedanum cervaria and $P$. alsaticum. Chemistry and Biodiversity, 7(11), 27482754.

Tabanca, N., Gao, Z., Demirci, B., Techen, N., Wedge, D. E., Ali, A., Sampson, B. J., Werle, C., Bernier, U. R., Khan, I. A., Baser, K. H. C., 2014. Molecular and Phytochemical Investigation of Angelica dahurica and Angelica pubescentis
Essential Oils and their Biological Activity against Aedes aegypti, Stephanitis pyrioides, and Colletotrichum Species. Journal of Agricultural and Food Chemistry, 62(35), 8848-8857.

Xu, Y., Li, H., Li, X., Xiao, X., Qian, P., 2009. Inhibitory Effects of a Branched-Chain Fatty Acid on Larval Settlement of the Polychaete Hydroides elegans. Marine Biotechnology, 11, 495-504. 